\title{
Spirituality and Medicine
}

\author{
A Workshop for Medical Students and Residents \\ Katherine Gergen Barnett, MS4, ${ }^{7}$ Auguste H. Fortin VI, MD, MPH ${ }^{2,3}$ \\ 'Yale University School of Medicine, New Haven, CT, USA; 'Department of Medicine, Yale University School of Medicine, New Haven, CT, \\ USA; ${ }^{3}$ Waterbury Hospital, Waterbury, CT, USA.
}

INTRODUCTION: Governing bodies for medical education recommend that spirituality and medicine be incorporated into training.

\begin{abstract}
AIM: To pilot a workshop on spirituality and medicine on a convenience sample of preclinical medical students and internal medicine residents and determine whether content was relevant to learners at different levels, whether preliminary evaluation was promising, and to generate hypotheses for future research.
\end{abstract}

SETTING: Private medical school and university primary care internal medicine residency program, both in the Northeast.

CURRICULUM DESCRIPTION: The authors designed and implemented a required 2-hour workshop for all second-year medical students and a separate required 1.5-hour workshop for all primary care internal medicine house staff. The workshops used multiple educational strategies including lecture, discussion, and role-play to address educational objectives.

PROGRAM EVALUATION: Learners completed optional, anonymous pre and postworkshop surveys with six 5-point Likert-rated statements and space to cite the most useful part of the curriculum and their remaining questions. One hundred and thirty-seven learners participated and 100 completed both surveys. Medical students and residents had increased (all $P \leq .002$ ): agreement regarding the appropriateness of inquiring about spiritual and religious beliefs in the medical encounter, their perceived competence in taking a spiritual history, and their perceived knowledge of available pastoral care resources. Medical students, but not residents, had an increase in their perceived comfort in working with hospital chaplains.

DISCUSSION: A brief pilot workshop on spirituality and medicine had a modest effect in improving attitudes and perceived competence of both medical students and residents.

KEY WORDS: spirituality; curriculum; medical education. DOI: $10.1111 / \mathrm{j} .1525-1497.2006 .00431 . \mathrm{X}$ J GEN INTERN MED 2006; 21:481-485.

$\mathrm{N}$ orth Americans are a spiritual people: in a 2000 Gallup poll, $91 \%$ reported a belief in God or a Universal Spirit, while $83 \%$ asserted that, "God is highly important in my life." In another poll of 1,000 U.S. adults, 79\% of respondents believed that spiritual faith can help people recover from disease and $63 \%$ felt that physicians should ask patients about their spiritual beliefs. ${ }^{2}$ Although many patients are hoping for their spiritual and religious beliefs to be addressed by their doctors, most physicians do not ask. ${ }^{3-5}$ Cited barriers to asking include: lack of time; lack of training in taking a spiritual history; uncertainty about how to identify patients with spiritual needs; concern about projecting beliefs onto patients; uncertainty about how to manage spiritual issues raised by pa-

Presented in part at the Society for General Internal Medicine, New England Region Meeting, 2001.

Address correspondence and requests for reprints to Dr. Fortin: Office of Education, Yale University School of Medicine, 367 Cedar Street, New Haven, CT 06510-3240 (e-mail: auguste.fortin@yale.edu). tients $^{6}$; discomfort ${ }^{7}$; role uncertainty (e.g., working with chaplains) ${ }^{8}$; and lack of awareness of the importance of belief to patients. ${ }^{9}$

To address these concerns, governing bodies for medical education, such as the Association of American Medical Colleges, have recommended that spirituality and religion be incorporated into medical training. ${ }^{10}$ Currently, 80 of the nation's 126 accredited medical schools are offering courses on spirituality and medicine, up from 1 in $1992 .{ }^{11}$ The content for these courses has been suggested, ${ }^{12-14}$ but few curricula have been reported in the literature, ${ }^{15}$ and there has been little empirical research on the ideal targeted learners, content, implementation, and efficacy of such courses.

Faced with limited curricular time for new courses, we developed and piloted a brief workshop on spirituality and medicine. We sought to determine whether the content was relevant to learners at different levels, whether preliminary evaluation was promising, and to generate hypotheses for future research.

\section{CURRICULUM DESCRIPTION}

\section{Subjects}

One of us (A.H.F.) had curricular responsibility for second-year medical students and primary care internal medicine interns and residents, both at a private Northeast university. For expediency, we involved these learners in the pilot project.

\section{Curriculum}

In 2000 , we performed a needs assessment ${ }^{16}$ by reviewing the medical school's preclinical curriculum and the residency program's didactic curriculum to determine existing spirituality and medicine content. None was noted. We informally interviewed residents and found that they had little or no contact with hospital chaplains. We searched the literature for expert suggestions and reported curricula ${ }^{12-14,17}$ and, based on this information, developed specific learner objectives (listed in Table 1, column 2) and educational strategies to address these objectives (Table 1, columns 1 and 4). ${ }^{16}$

The medical student workshop was 2 hours long and was presented as part of a required Doctor-Patient Encounter course, while the separate resident workshop was oneand-one-half hours long and was given during a required ambulatory block rotation. Each workshop accommodated approximately 20 learners and was repeated to train all 105 second-year students and all 60 primary care residents in the 2000 to 2001 academic year. One of 3 physician instructors presented each student workshop; 1 physician instructor presented all the resident workshops. To help standardize delivery, instructors attended a training session and used the same PowerPoint presentation and speaker's notes for all workshops (Appendix A). 
Learners received a handout covering key concepts (Appendix B) and a spiritual assessment pocket card (Appendix C). There were no advance readings. We used several instructional strategies in specific sequence to meet the educational objectives (Table 1). The workshops began with a brief review of the medical interview to provide context for including a spiritual assessment as part of the social history ${ }^{18}$ and care of the whole person. ${ }^{19}$ The instructor continued by engaging learners in a discussion of the similarities and differences between spirituality and religion, as experts stress the importance of appreciating spirituality's broader context with both religious and nonreligious meanings. ${ }^{20}$ Learners provided their definitions, which were written on a blackboard and compared with standard definitions from the literature ${ }^{12,20-23}$ to help learners appreciate the multidimensionality of both spirituality and religion.

The demographics of spirituality and religion in America ${ }^{24}$ and the apparent differences in levels of spirituality/religiosity between the public and physicians ${ }^{25}$ were then presented in a mini-lecture. This was in order for learners to understand the prevalence and breadth of spirituality among Americans and possible reasons why Medicine has not addressed this topic until recently.

To introduce the potential clinical relevance of spirituality, the instructor reviewed research showing the importance of spirituality to many patients ${ }^{3-5}$ and briefly summarized studies associating religious beliefs/spirituality and health, ${ }^{26}$ including illness prevention, ${ }^{23,27,28}$ coping with illness, ${ }^{23,28-30}$ and improving illness outcomes. ${ }^{28}$ Some criticisms of this field of research were also presented. ${ }^{31}$

The instructor then facilitated discussions among learners about the potential harm of patients' religious or spiritual beliefs to their health and health care (e.g., religion-motivated medical neglect, spiritual crises) ${ }^{30,32-34}$ and the importance of professional boundaries when assessing spirituality. ${ }^{31,32,35-37}$ To demonstrate how religious beliefs can affect provision of medical care, the instructor presented the example of Jehovah's Witnesses' proscription against blood transfusions. ${ }^{38,39}$ Learners discussed how physicians' own beliefs could impede the doctor-patient relationship. ${ }^{36}$ They then brainstormed potential barriers that they might have to assessing patients' spirituality in the medical encounter. Reported physician barriers were also presented. ${ }^{6,7}$

Next, the instructor introduced a mnemonic to guide spiritual assessment. ${ }^{40}$ The mnemonic is FICA for Faith and beliefs, their Importance to patients, membership in a religious Community, and how patients would like clinicians to further Address the issue in their health care. Learners used the mnemonic to take a spiritual assessment of one another in pairs and then regrouped to debrief the experience. Those uncomfortable discussing their own spirituality were invited to make up answers for this exercise.

In the student workshop, a hospital chaplain then introduced and discussed the role of pastoral services and pastoral

Table 1. Workshop Topics, Objectives, and Timeline

\begin{tabular}{|c|c|c|c|c|}
\hline Workshop Component & $\begin{array}{l}\text { Learners' Objectives: By the End of the Workshop, } \\
\text { Learners Will be Able }\end{array}$ & $\begin{array}{l}\text { Time } \\
\text { Allotted }\end{array}$ & $\begin{array}{l}\text { Instructional } \\
\text { Strategy }\end{array}$ & References \\
\hline $\begin{array}{l}\text { "Asking about } \\
\text { spirituality } \\
\text { in the social history" }\end{array}$ & $\begin{array}{l}\text { To describe the context for spiritual assessment } \\
\text { in the social history }\end{array}$ & $\begin{array}{l}\text { Students } 10 \mathrm{~min} \\
\text { Residents } 5 \mathrm{~min}\end{array}$ & Mini-lecture & 18,19 \\
\hline $\begin{array}{l}\text { "Spirituality" vs } \\
\text { "religion" }\end{array}$ & $\begin{array}{l}\text { To distinguish spirituality's broader context with both } \\
\text { religious and non-religious meanings }\end{array}$ & $15 \mathrm{~min}$ & $\begin{array}{l}\text { Discussion, mini- } \\
\text { lecture }\end{array}$ & 20 \\
\hline $\begin{array}{l}\text { "Spirituality and } \\
\text { religion in America" }\end{array}$ & $\begin{array}{l}\text { To describe the prevalence of spirituality and religion in America } \\
\text { To understand why Medicine has not addressed this topic } \\
\text { until recently }\end{array}$ & $10 \mathrm{~min}$ & Mini-lecture & 24,25 \\
\hline $\begin{array}{l}\text { "Spirituality, health, } \\
\text { and illness" }\end{array}$ & $\begin{array}{l}\text { To rate as valuable the importance of spirituality to many } \\
\text { patients } \\
\text { To rate spiritual assessment as important* } \\
\text { To describe outcomes of research associating spirituality } \\
\text { and health } \\
\text { To understand some criticisms of this research }\end{array}$ & $15 \min$ & Mini-lecture & $23,26-31$ \\
\hline $\begin{array}{l}\text { "Potential health harms } \\
\text { of religious beliefs" }\end{array}$ & $\begin{array}{l}\text { To agree that patients' religious beliefs can potentially } \\
\text { harm their health and health care* }\end{array}$ & $10 \mathrm{~min}$ & Discussion & $30,32-34$ \\
\hline $\begin{array}{l}\text { "Specific beliefs and } \\
\text { healthcare provision: the } \\
\text { example of Jehovah's } \\
\text { Witnesses" }\end{array}$ & $\begin{array}{l}\text { To describe how patients' religious beliefs can affect the } \\
\text { provision of health care }\end{array}$ & $10 \mathrm{~min}$ & Mini-lecture & 38,39 \\
\hline $\begin{array}{l}\text { "Barriers to and } \\
\text { boundaries in } \\
\text { addressing spirituality } \\
\text { in the doctor-patient } \\
\text { encounter" }\end{array}$ & $\begin{array}{l}\text { To rate as valuable the need for professional boundaries } \\
\text { in assessing patients' spirituality/religion } \\
\text { To recognize that physicians' spiritual or religious beliefs } \\
\text { can affect their provision of health care* } \\
\text { To list physicians' barriers to spiritual assessment }\end{array}$ & $10 \mathrm{~min}$ & $\begin{array}{l}\text { Brainstorm, } \\
\text { discussion }\end{array}$ & $\begin{array}{l}6,7,31,32, \\
35-37\end{array}$ \\
\hline $\begin{array}{l}\text { "Spiritual assessment } \\
\text { techniques" }\end{array}$ & $\begin{array}{l}\text { To recite a mnemonic for spiritual assessment } \\
\text { To practice a spiritual assessment of a colleague* }\end{array}$ & $25 \min$ & $\begin{array}{l}\text { Mini-lecture, role } \\
\text { play, discussion }\end{array}$ & 40 \\
\hline $\begin{array}{l}\text { "Pastoral care referral } \\
\text { resources }\end{array}$ & $\begin{array}{l}\text { To receive a list of available pastoral care resources } \\
\text { To express increased comfort in working with hospital } \\
\text { chaplains* } \\
\text { To rate increased competence in consulting pastoral } \\
\text { care services* }\end{array}$ & $\begin{array}{l}\text { Students } 15 \mathrm{~min} \\
\text { Residents } 5 \mathrm{~min}\end{array}$ & $\begin{array}{l}\text { Mini-lecture, } \\
\text { discussion }\end{array}$ & \\
\hline
\end{tabular}

*Objectives assessed. 
consultation in the inpatient and outpatient setting. For logistical reasons, there was no chaplain present in the resident workshop; instead, the physician instructor briefly discussed chaplains' roles and handed out an information sheet on obtaining pastoral consultation at the hospitals where the residents rotate.

\section{CURRICULUM EVALUATION}

For this pilot, we chose to assess a subset of the curricular objectives. Learners completed voluntary, anonymous surveys, approved by the human investigations committee, both immediately before and after the workshop. The surveys contained 6 statements on attitudes toward spirituality and medicine, perceived competence in taking a spiritual history, perceived knowledge of pastoral care resources, and comfort working with hospital chaplains (Table 2, column 1). Learners rated their agreement on a 5 -point Likert scale $(1=$ strongly disagree, $5=$ strongly agree). In the postworkshop survey, there was also a space for learners to cite the most useful parts of the curriculum and their remaining questions about spirituality/religion in health care. Demographic information was not collected.

\section{Data Analysis}

Standard frequencies and means were calculated for individual variables. Because the data were not normally distributed, we used nonparametric tests for comparisons. Changes in survey responses before and after the workshops were analyzed with the Wilcoxon rank-sum test for paired data. Differences between students' and residents' responses were analyzed using the Mann-Whitney $U$ test. Applying the Bonferroni correction to account for correlated responses set significance at $P<.003$. In order to analyze learners' citations of the most useful parts of the workshop and their remaining questions, we used the constant comparative method of qualitative data analysis, ${ }^{41}$ whereby themes were generated and repeatedly assessed until a mutually exclusive set of themes was derived and the interrater agreement was 100\%.

\section{Results}

The workshops were attended by 79 of 105 medical students $(75 \%)$ and 58 of $60(97 \%)$ primary care medical interns and residents. Pre and postworkshop surveys were completed by 54 students (68\%) and 46 residents (79\%); the difference in response rates was not significant.

Table 2 shows learners' Likert survey scores and changes after the workshop. Both medical students and residents increased scores (all $P \leq .002$ ) regarding the appropriateness of inquiring about spiritual and religious beliefs in the medical encounter, perceived competence in taking a spiritual history, and perceived knowledge of available pastoral care resources. Medical students, but not residents, increased their perceived comfort in working with others on the health care team who emphasize patients' spirituality, such as chaplains. This difference between students and residents approached significance $(P=$.005). On the item, "A physician's spiritual/religious beliefs can affect his/her ability to communicate with and care for patients," the difference in pre to postworkshop scores between students and residents achieved significance.

The most useful workshop components cited by learners were as follows: knowledge gained (i.e., information on pastoral referral resources, the spiritual history mnemonic, and demographics of spirituality in the United States); the opportunity to discuss and reflect upon this subject in a safe environment; and the skill of how to take a spiritual history. Research associating spirituality/religion and health was least cited as useful.

The most common questions remaining for learners after the workshop concerned appropriateness (e.g., "Is it a physician's role?" "For which patients it is appropriate?") and spiritual history-taking (e.g., when to ask, the extent to ask, and how to ask so that the patient is comfortable).

\section{DISCUSSION}

Overall, the results from this pilot study of a brief workshop in spirituality and medicine indicate a modest effect on medical students' and primary care residents' attitudes regarding the appropriateness of taking a spiritual history, perceived knowledge about accessing pastoral care resources, and perceived competence in asking patients about their spiritual or religious beliefs. These pilot results are encouraging as already crowded curricula can make more extensive courses difficult to implement.

Table 2. Pre and Postworkshop Survey Scores of Students and Residents

\begin{tabular}{|c|c|c|c|c|}
\hline Item & & $\begin{array}{l}\text { Precourse } \\
\text { Mean (SD) }\end{array}$ & $\begin{array}{l}\text { Postcourse } \\
\text { Mean (SD) }\end{array}$ & $\begin{array}{l}\text { Mean } \\
\text { Change }(P)\end{array}$ \\
\hline \multirow{2}{*}{$\begin{array}{l}\text { 1. "Asking about a patient's spiritual or religious beliefs is an appropriate } \\
\text { part of patient care" }\end{array}$} & Students & $3.8(0.9)$ & $4.1(1.0)$ & $+0.4(.002)$ \\
\hline & Residents & $3.8(0.9)$ & $4.3(0.6)$ & $+0.6(<.001)$ \\
\hline \multirow[t]{2}{*}{ 2. "A patient's spiritual/religious beliefs can impact his or her health" } & Students & $4.4(0.7)$ & $4.3(1.0)$ & $-0.1(.38)$ \\
\hline & Residents & $4.6(0.5)$ & $4.6(0.5)$ & $0(.7)$ \\
\hline \multirow{2}{*}{$\begin{array}{l}\text { 3. "A physician's spiritual/religious beliefs can affect his/her ability to } \\
\text { communicate with and care for patients" }\end{array}$} & Students & $3.5(1.3)$ & $3.3(1.3)$ & $-0.4(.03) *$ \\
\hline & Residents & $3.9(0.8)$ & $4.1(0.7)$ & $+0.2(.02)$ \\
\hline \multirow{2}{*}{$\begin{array}{l}\text { 4. "I am comfortable working with people in other fields who emphasize } \\
\text { caring for patients' spirituality, such as hospital chaplains" }\end{array}$} & Students & $3.7(1.0)$ & $4.1(0.9)$ & $+0.5(.001)$ \\
\hline & Residents & $4.0(0.8)$ & $4.0(0.8)$ & $0(.8)$ \\
\hline \multirow[t]{2}{*}{ 5. "I feel competent taking a patient's spiritual history" } & Students & $2.7(1.0)$ & $3.7(0.9)$ & $+1.0(<.001)$ \\
\hline & Residents & $3.2(0.8)$ & $3.9(0.7)$ & $+0.7(<.001)$ \\
\hline \multirow{2}{*}{$\begin{array}{l}\text { 6. "I know to whom to refer a patient with a spiritual or religious question, } \\
\text { concern, or crisis" }\end{array}$} & Students & $2.8(1.2)$ & $4.2(0.8)$ & $+1.5(<.001)$ \\
\hline & Residents & $3.0(1.2)$ & $4.1(0.8)$ & $+1.2(<.001)$ \\
\hline
\end{tabular}

1, strongly disagree to 5, strongly agree scale.

${ }^{*} \mathrm{P}=.002$ for difference between students and residents. 
Identifying appropriate content for curricula in spirituality and medicine may aid future curriculum developers. Our learners already arrived at the workshop tending to agree that spiritual assessment was appropriate and that patients' beliefs could impact health; workshop time could perhaps have been spent on other content. Conversely, the most frequent question remaining for learners after the workshop related to issues of appropriateness. This needs further research. Learners most valued receiving information (the demographics of spirituality in the Unites States, local pastoral referral resources), learning and practicing the spiritual history mnemonic and being able to discuss the topic in a safe environment.

One of the workshop objectives was for learners to recognize how physicians' spiritual or religious beliefs can affect their provision of health care. In fact, students remained nearly neutral in their agreement with this statement compared with residents, despite discussing examples of physicians proselytizing patients or being judgmental on religious grounds. We hypothesize that a more positive attitude toward the topic of spirituality and medicine after the workshop may have led them to feel that they could exhibit appropriate professionalism. Preclinical students lack the clinical context and experience of residents, so the discussion may have been more theoretical for them. Finally, the wording of the survey item \#3 was ambiguous because "affect" has both positive and negative connotations.

Medical students, but not residents, significantly increased their perceived comfort in working with hospital chaplains; this may represent an unintended training effect because of the involvement of a hospital chaplain in only the students' workshops ${ }^{42}$ or a ceiling effect among the residents, although students' and residents' perceived comfort did not differ significantly before the workshop.

The workshop content appears to have been relevant to both medical students and residents, suggesting that such curricula may be appropriate to introduce in both medical school and residency. While residents may have a more immediate need, if students are not exposed to this information before they start clinical rotations, they may miss opportunities to assess spirituality in their new patients. Students also have more time than others on the team to elicit a social history and thus may be better able to uncover a patient's spiritual or religious crisis or concern.

Our workshop had several limitations. Although it was required, $25 \%$ of medical students did not attend. This rate did not differ significantly from attendance at other sessions in the doctor-patient encounter course but, as we did not collect demographic data on participants versus nonparticipants, we cannot comment on how their absence impacted our results. There was no comparison group, although the immediate posttest makes it unlikely that any other intervention could have accounted for the observed changes. The workshop was offered only once to learners; lasting change in knowledge, skills, and attitudes may be more likely if a topic is integrated into the larger curriculum and introduced repeatedly. ${ }^{43}$ Our workshop was only studied in 1 private medical school preclinical class and 1 university primary care internal medicine residency program, both in the Northeast, thereby limiting the generalizability of our results. Clinical medical students or residents from other specialties may have responded differently. The workshops were not identical within and between groups of learners, so differences in survey responses may be attribut- able to differences in the intervention rather than differences between the groups. For example, a chaplain participated only in the students' workshops. The students' workshops were led by 3 different instructors, while the residents' workshops had the same instructor. The instructors received identical training and used the same curricular material, but individual presentation styles or delivery may have affected survey responses. We did not use dated surveys so we could not assess for such an effect.

Our evaluation method also had weaknesses. Instructors and students were not blinded. It is possible that social desirability bias or a wish to please the investigators affected learners' survey responses. This is mitigated somewhat by the anonymity of the surveys. Learners completed the postworkshop survey immediately after the workshop concluded, whereas testing 1 to 3 months afterward may have allowed for initial "decay" of knowledge, skills, and attitudes and may have represented a more stable change. Thirty-two percent of students and $21 \%$ of residents did not contribute data to the analyses; because the surveys were anonymous, we cannot determine how nonresponders differed from responders, or how the loss of sample may impact our results. We evaluated only a subset of our educational objectives. While we presented both potential salutary and harmful effects of patients' spiritual/religious belief, the wording of survey question \#2 assessing learners' attitude on these items did not discriminate beneficial from deleterious effects. Finally, our outcome measures relied on self-reports rather than actual behavior change.

Further research is needed to determine whether improvements in attitudes, perceived knowledge, and perceived skills persist over time; whether medical students and residents who complete such a workshop are more likely to perform spiritual assessments with their patients and request pastoral care consultations; and how best to integrate this topic into the larger medical school and residency curriculum. As more medical schools offer training in this area, needs of future residents will likely change. Learners' questions about the appropriateness of spiritual assessment may be best answered by introducing the ethic of discourse about ultimate human concerns. ${ }^{44,45}$

The authors thank Margaret Bia, MD, for her vision and guidance during the development and implementation of this curriculum, Andre Sofair, MD, MPH, for helping to teach the workshop, Rev. Margaret Lewis for helping to teach the workshop and assisting with the qualitative analysis, Michael Green, $M D, M S c$, for statistical assistance, and Patrick O'Connor, MD, $M P H$, and Robert Smith, MD, SCM, for reading earlier drafts of this paper. We also thank the Yale University School of Medicine class of 2003 and the Yale Primary Care residents for their adventuresome spirits and honest feedback. This project was supported in part by a John Templeton Foundation Grant for Curricula on Spirituality, Culture and End-of-Life Care. The funding organization had no role in the design and conduct of the study, in the collection, analysis, and interpretation of the data, or in the preparation, review, or approval of the manuscript.

\section{REFERENCES}

1. Carballo M. Gallup International Millennium Survey. Available at: http://www.gallup-international.com/survey 15.htm.

2. McNichol T. The new faith in medicine. USA Today. April 7, 1996:4.

3. King DE, Bushwick B. Beliefs and attitudes of hospital inpatients about faith healing and prayer. J Fam Prac. 1994;39:349-52. 
4. Daaleman TP, Nease DE. Patient attitudes regarding physician inquiry into spiritual and religious issues [see comments]. J Fam Prac. 1994; 39:564-8.

5. Ehman JW, Ott BB, Short TH, Ciampa RC, Hansen-Flaschen J. Do patients want physicians to inquire about their spiritual or religious beliefs if they become gravely ill? Arch Intern Med. 1999;159:1803-6.

6. Ellis MR, Vinson DC, Ewigman B. Addressing spiritual concerns of patients: family physicians' attitudes and practices [see comments]. J Fam Prac. 1999;48:105-9.

7. Chibnall JT, Brooks CA. Religion in the clinic: the role of physician beliefs. South Med J. 2001;94:374-9.

8. Kristeller JL, Zumbrun CS, Schilling RF. "I would if I could": how oncologists and oncology nurses address spiritual distress in cancer patients. Psychooncology. 1999;8:451-8.

9. Jones AW. A survey of general practitioners' attitudes to the involvement of clergy in patient care. Br J General Prac. 1990;40:280-3.

10. Association of American Medical Colleges. Report III of the medical school objectives project. Contemporary issues in medicine: communication in medicine; 1999.

11. Puchalski C. Spirituality in health: the role of spirituality in critical care. Crit Care Clin. 2004;20:487-504.

12. Puchalski CM, Larson DB. Developing curricula in spirituality and medicine. [erratum appears in Acad Med 1998;73:1038]. Acad Med. 1998;73:970-4.

13. Barnard D, Dayringer R, Cassel CK. Toward a person-centered medicine: religious studies in the medical curriculum. Acad Med. 1995;70: 806-13.

14. Silverman HD. Creating a spirituality curriculum for family practice residents. Altern Ther Health Med. 1997;3:54-61.

15. Fortin AH VI, Gergen Barnett K. Medical school curricula in spirituality and medicine. JAMA. 2004;291:2883.

16. Kern DE. Curriculum Development for Medical education: A Six Step Approach. Baltimore: Johns Hopkins University Press; 1998.

17. Deloney LA, Graham CJ, Erwin Do. Presenting cultural diversity and spirituality to first-year medical students. Acad Med. 2000;75:513-4.

18. Smith RC. Patient Centered Interviewing. 2nd edn. Philadelphia: Lippincott Williams \& Wilkins; 2002.

19. McKee DD, Chappel JN. Spirituality and medical practice. [see comments]. J Fam Prac. 1992;35:201.

20. Anandarajah G, Hight E. Spirituality and medical practice: using the HOPE questions as a practical tool for spiritual assessment. Am Fam Physician. 2001;63:81-9.

21. Hunter RJ. Dictionary of Pastoral Care and Counseling. Nashville: Abingdon Press; 1990.

22. Matthews DA, Classen DC, Willms JL, Cotton JP. A program to help interns cope with stresses in an internal medicine residency. J Med Educ. 1988;63:539-47.

23. Mueller PS, Plevak DJ, Rummans TA. Religious involvement, spirituality, and medicine: implications for clinical practice. [see comments]. Mayo Clinic Proc. 2001;76:1225-35.

24. Gallup G Princeton Religion Research Center. Religion in America 1990. Princeton, NJ: Princeton Religion Research Center; 1990.

\section{Supplementary Material}

The following supplementary material is available for this article online at www.blackwell-synergy.com

Appendix A. PowerPoint Presentation.

Appendix B. Handout.

Appendix C. FICA Pocket Card.
25. Daaleman TP, Frey B. Spiritual and religious beliefs and practices of family physicians: a national survey. [see comments]. J Fam Prac. 1999; 48:98-104.

26. Levin JS. How religion influences morbidity and health: reflections on natural history, salutogenesis and host resistance. Soc Sci Med. 1996; 43:849-64.

27. Koenig HG, Hays JC, Larson DB, et al. Does religious attendance prolong survival? A six-year follow-up study of 3,968 older adults. J Gerontol Series A-Biol Sci Med Sci. 1999;54:M370-6.

28. Matthews DA, McCullough ME, Larson DB, Koenig HG, Swyers JP, Milano MG. Religious commitment and health status: a review of the research and implications for family medicine. Arch Fam Med. 1998; $7: 118-24$.

29. McBride JL, Arthur G, Brooks R, Pilkington L. The relationship between a patient's spirituality and health experiences. Fam Med. 1998; 30: $122-6$.

30. Kaldjian LC, Jekel JF, Friedland G. End-of-life decisions in HIV-positive patients: the role of spiritual beliefs. AIDS. 1998;12:103-7.

31. Sloan RP, Bagiella E, Powell T. Religion, spirituality, and medicine. [see comments]. Lancet. 1999;353:664-7.

32. Post SG, Puchalski CM, Larson DB. Physicians and patient spirituality: professional boundaries, competency, and ethics. Ann Intern Med. 2000; 132:578-83.

33. Asser SM, Swan R. Child fatalities from religion-motivated medical neglect. Pediatrics. 1998;101(part 1):625-9.

34. Pargament KI, Koenig HG, Tarakeshwar N, Hahn J. Religious struggle as a predictor of mortality among medically ill elderly patients: a 2-year longitudinal study. Arch Intern Med. 2001;161:1881-5.

35. Koenig HG. Religion and medicine I: historical background and reasons for separation [see comments]. Int J Psychiatry Med. 2000;30:385-98.

36. Sloan RP, Bagiella E, VandeCreek L, et al. Should physicians prescribe religious activities? N Engl J Med. 2000;342:1913-6.

37. Astrow AB, Puchalski CM, Sulmasy DP. Religion, spirituality, and health care: social, ethical, and practical considerations. Am J Med. 2001;110:283-7.

38. Rutherford JF, Bergman J. Jehovah's Witnesses I: The Early Writings of J.F. Rutherford. New York: Garland Publication; 1990 (Cults and new religions; 8).

39. Bergman J. Jehovah's Witnesses II: Controversial and Polemical Pamphlets. New York: Garland Publication; 1990 (Cults and new religions; 9).

40. Puchalski C, Romer AL. Taking a spiritual history allows clinicians to understand patients more fully. J Palliat Med. 2000;3:129-37.

41. Crabtree BF, Miller WL. Doing Qualitative Research. Newbury Park, CA: Sage Publications; 1992 (Research methods for primary care; v. 3.).

42. Graves DL, Shue CK, Arnold L. The role of spirituality in patient care: incorporating spirituality training into medical school curriculum. Acad Med. 2002;77:1167.

43. Chibnall JT, Duckro PN. Does exposure to issues of spirituality predict medical students' attitudes toward spirituality in medicine? Acad Med. 2000;75:661.

44. Curlin FA, Hall DE. Strangers or friends? A proposal for a new spirituality-in-medicine ethic. J Gen Intern Med. 2005;20:370-4.

45. Scheurich N. Spirituality, medicine, and the possibility of wisdom. J Gen Intern Med. 2005;20:379-80. 